\title{
No Return Pictured
}

\author{
By
}

\section{Megan Thomas}




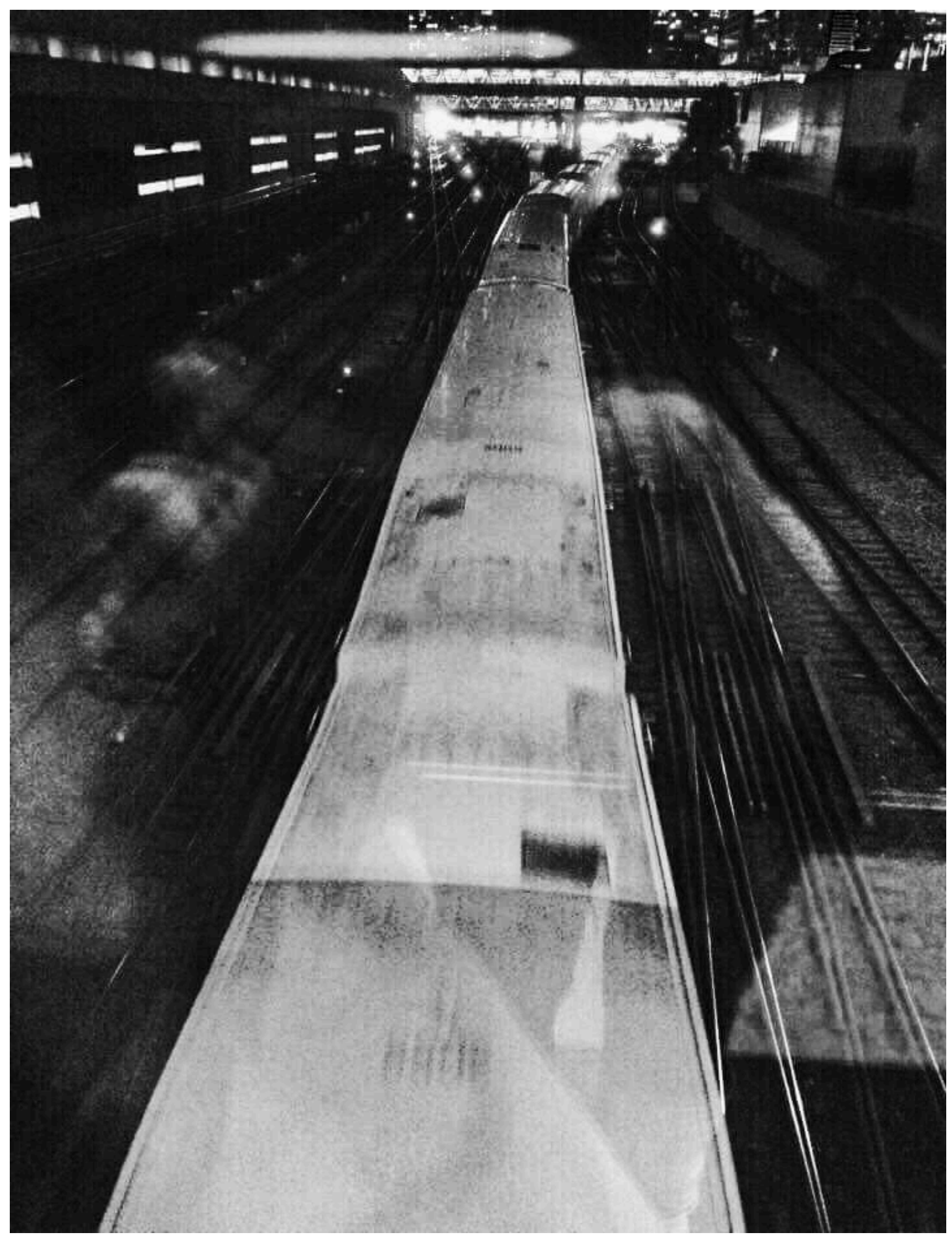

1. The Train

Cultural and Pedagogical Inquiry, Fall 2017, 9(2), pp. 27-42

ISSN 1916-3460 C 2017 University of Alberta

http://ejournals.library.ualberta.ca/index.php/cpi/index 


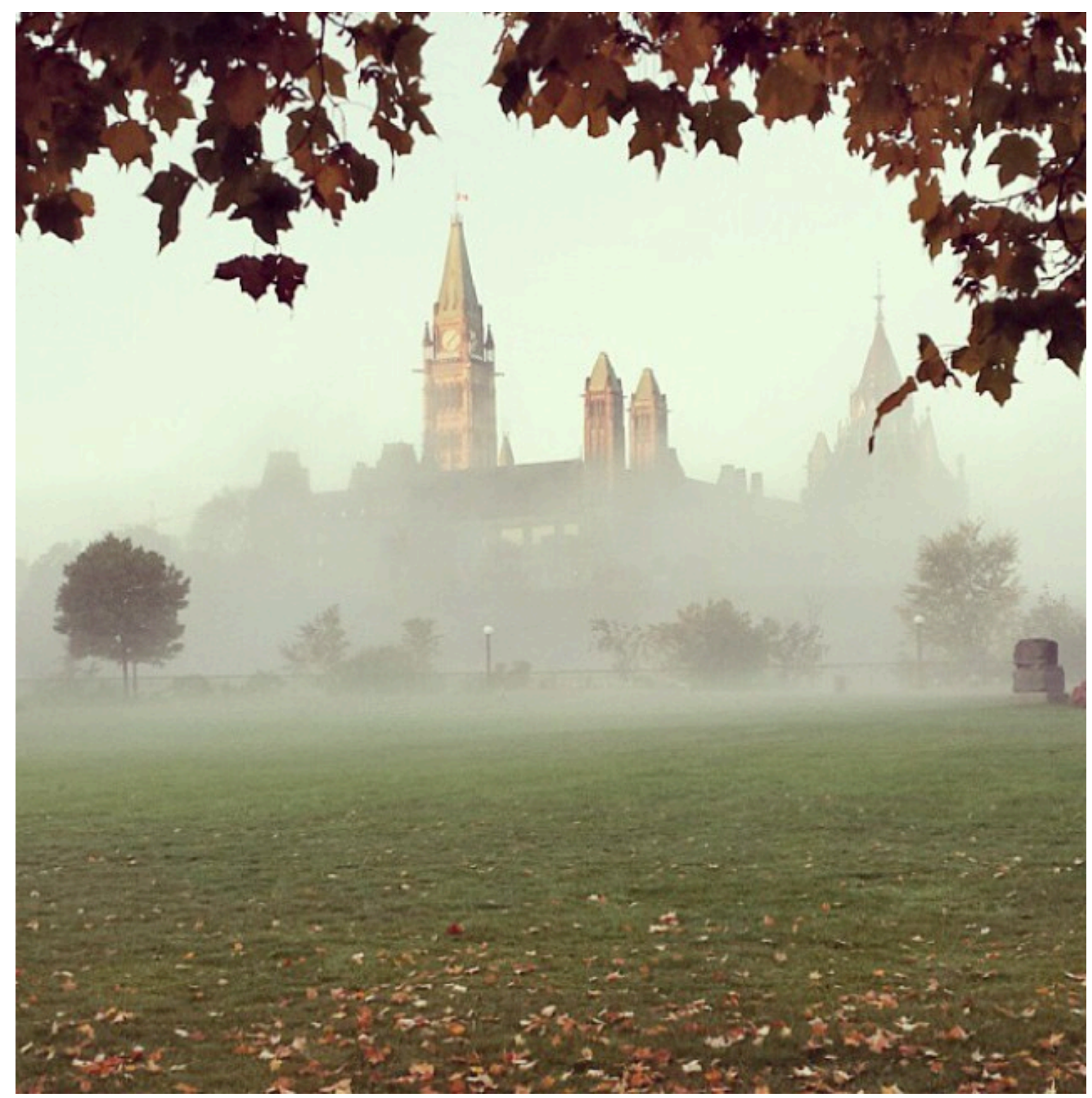

2. Disappearing Stories

Original photograph taken by Megan Thomas. Enhanced by Dilan O'Connor. 


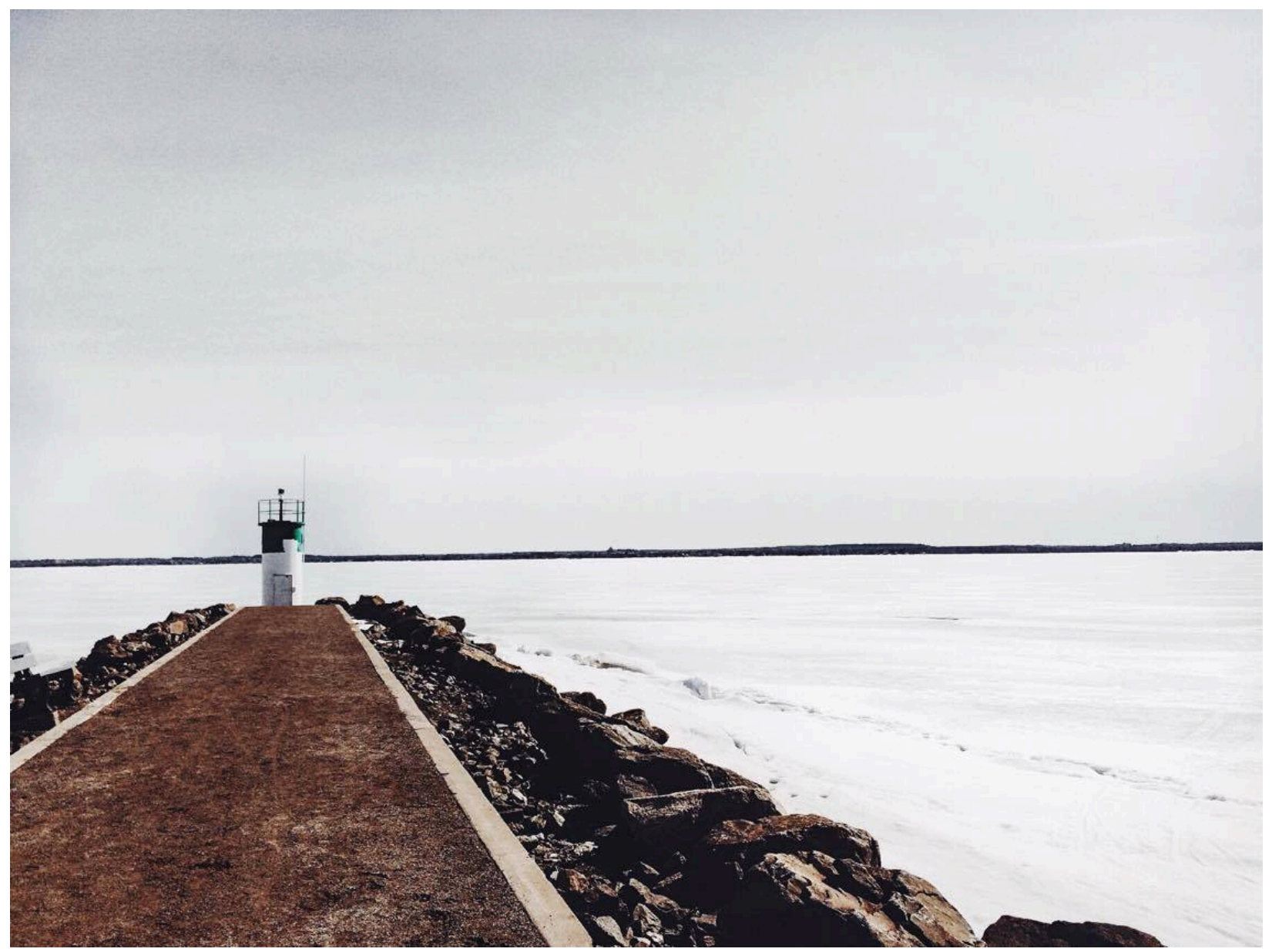

3. Lines

Cultural and Pedagogical Inquiry, Fall 2017, 9(2), pp. 27-42

ISSN 1916-3460 C 2017 University of Alberta

http://ejournals.library.ualberta.ca/index.php/cpi/index 


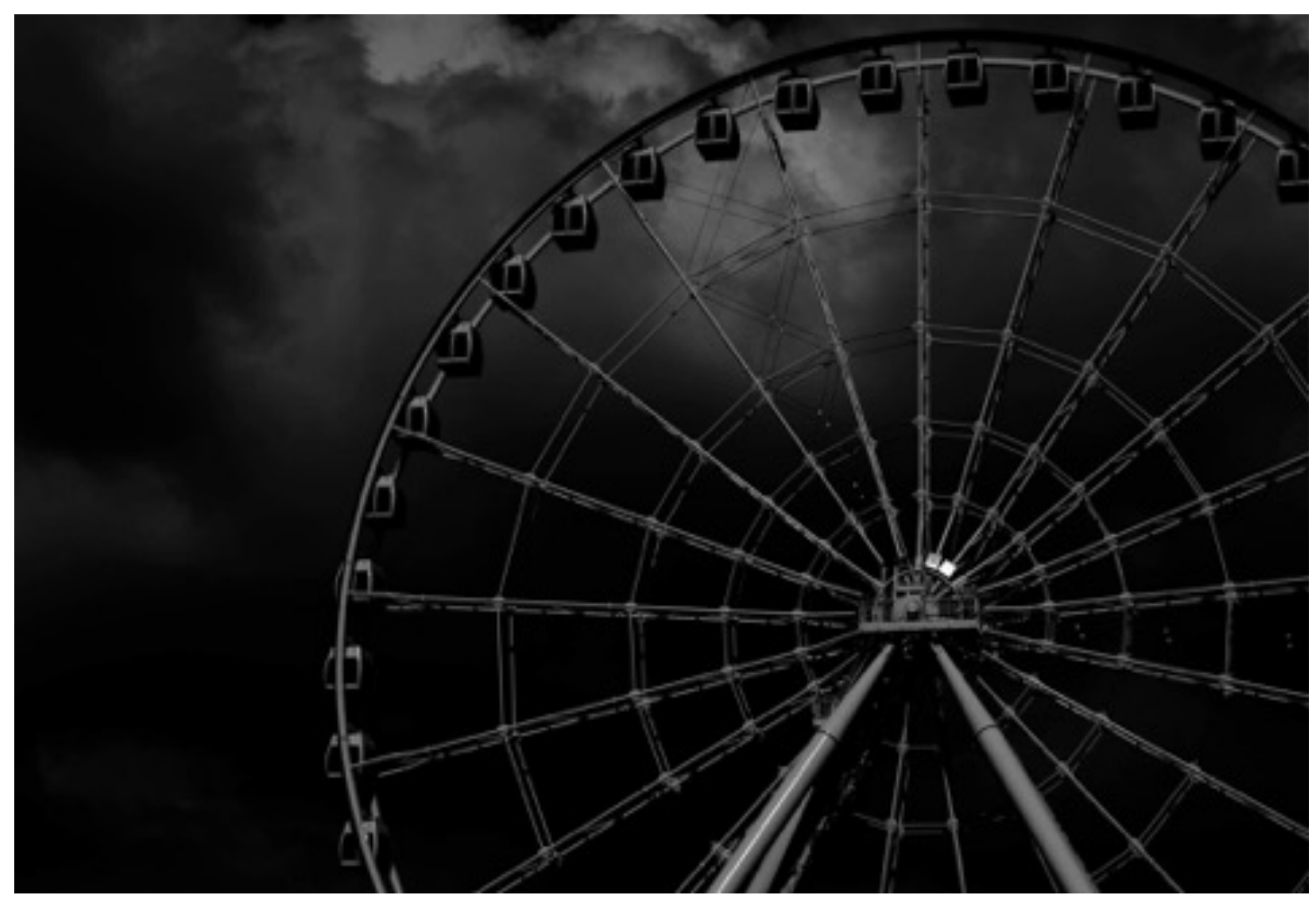

\section{Spokes}

Cultural and Pedagogical Inquiry, Fall 2017, 9(2), pp. 27-42

ISSN 1916-3460 C 2017 University of Alberta

http://ejournals.library.ualberta.ca/index.php/cpi/index 


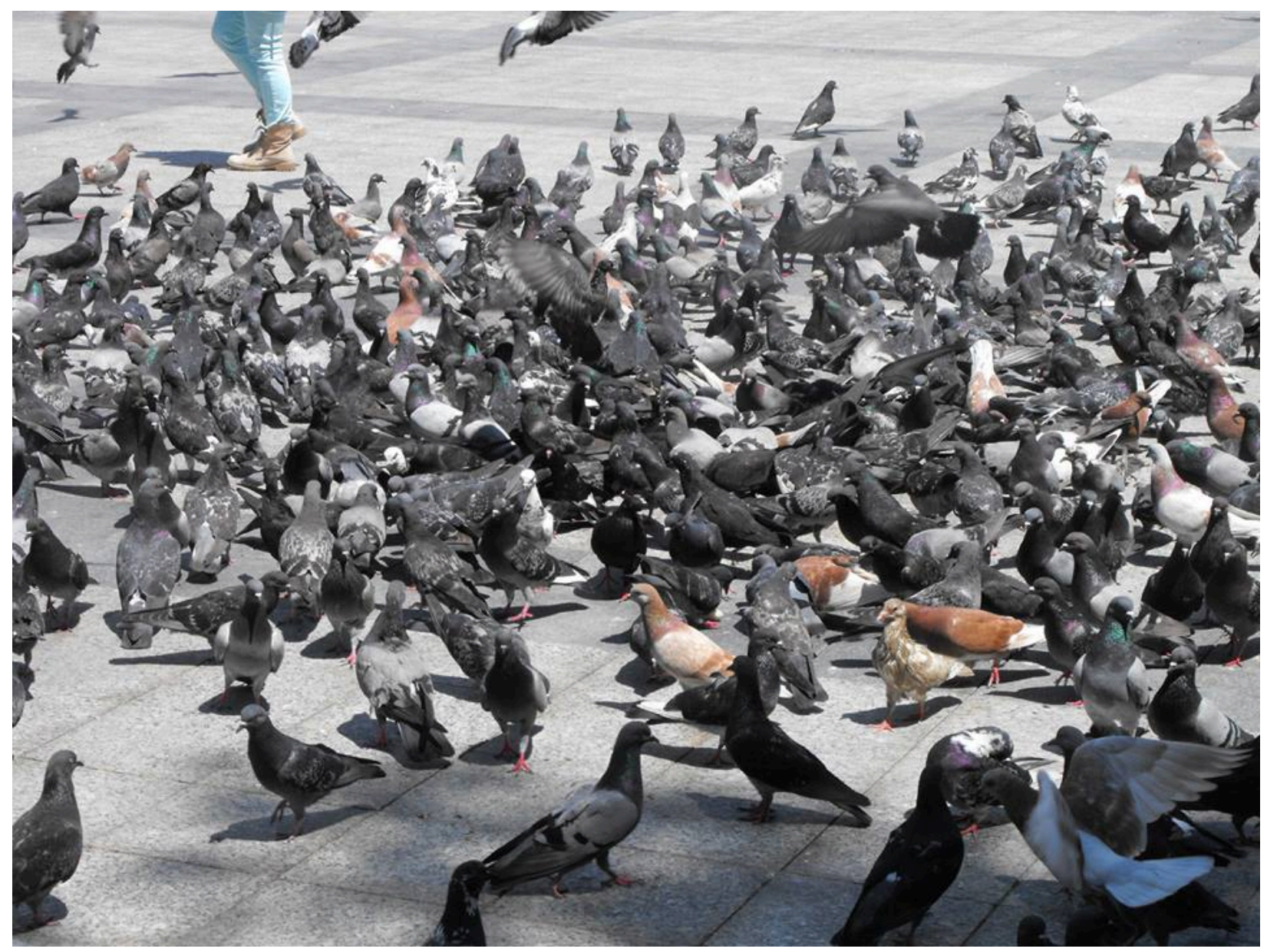

\section{The Many}

Cultural and Pedagogical Inquiry, Fall 2017, 9(2), pp. 27-42

ISSN 1916-3460 C 2017 University of Alberta

http://ejournals.library.ualberta.ca/index.php/cpi/index 


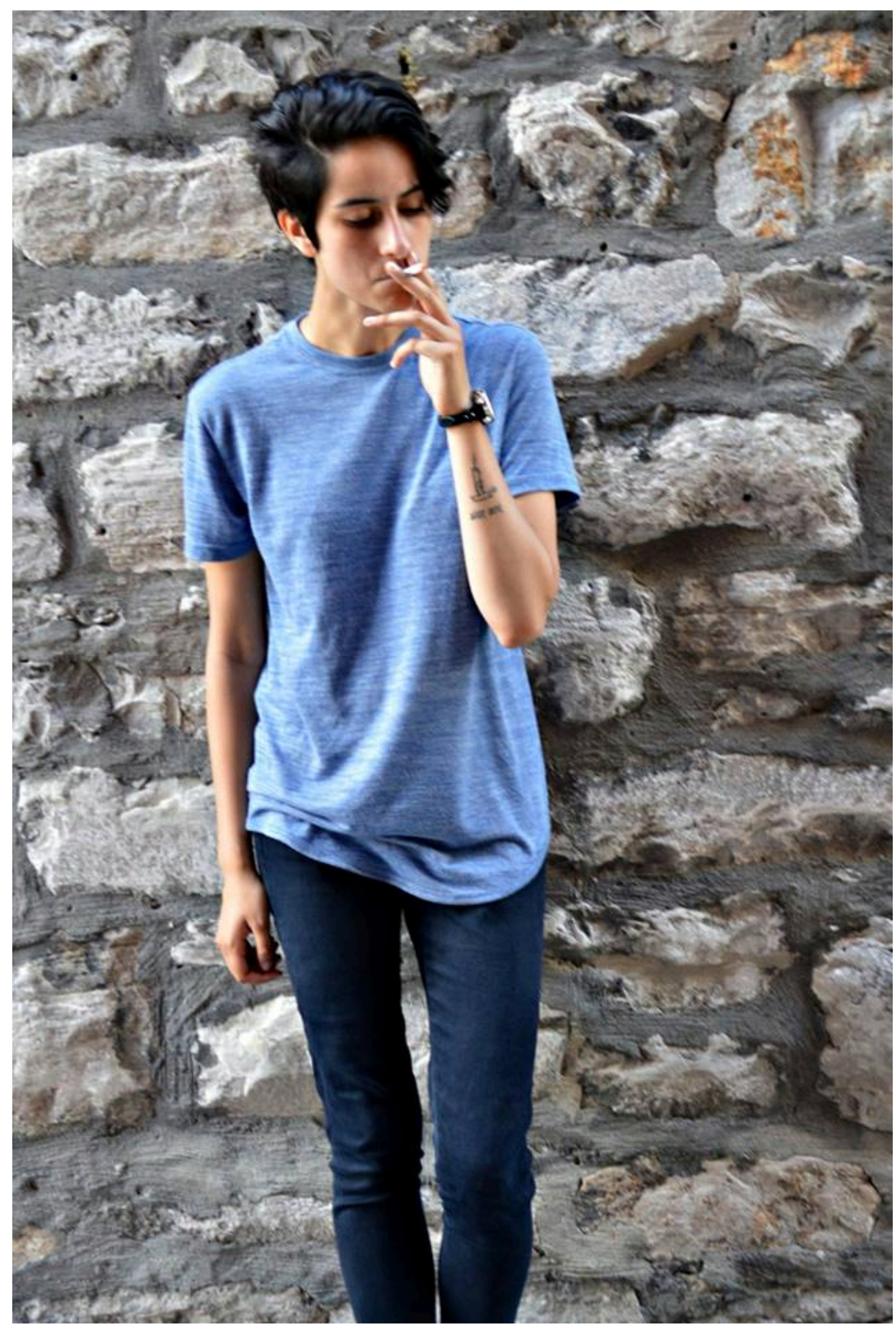

\section{After}

Cultural and Pedagogical Inquiry, Fall 2017, 9(2), pp. 27-42

ISSN 1916-3460 C 2017 University of Alberta

http://ejournals.library.ualberta.ca/index.php/cpi/index 


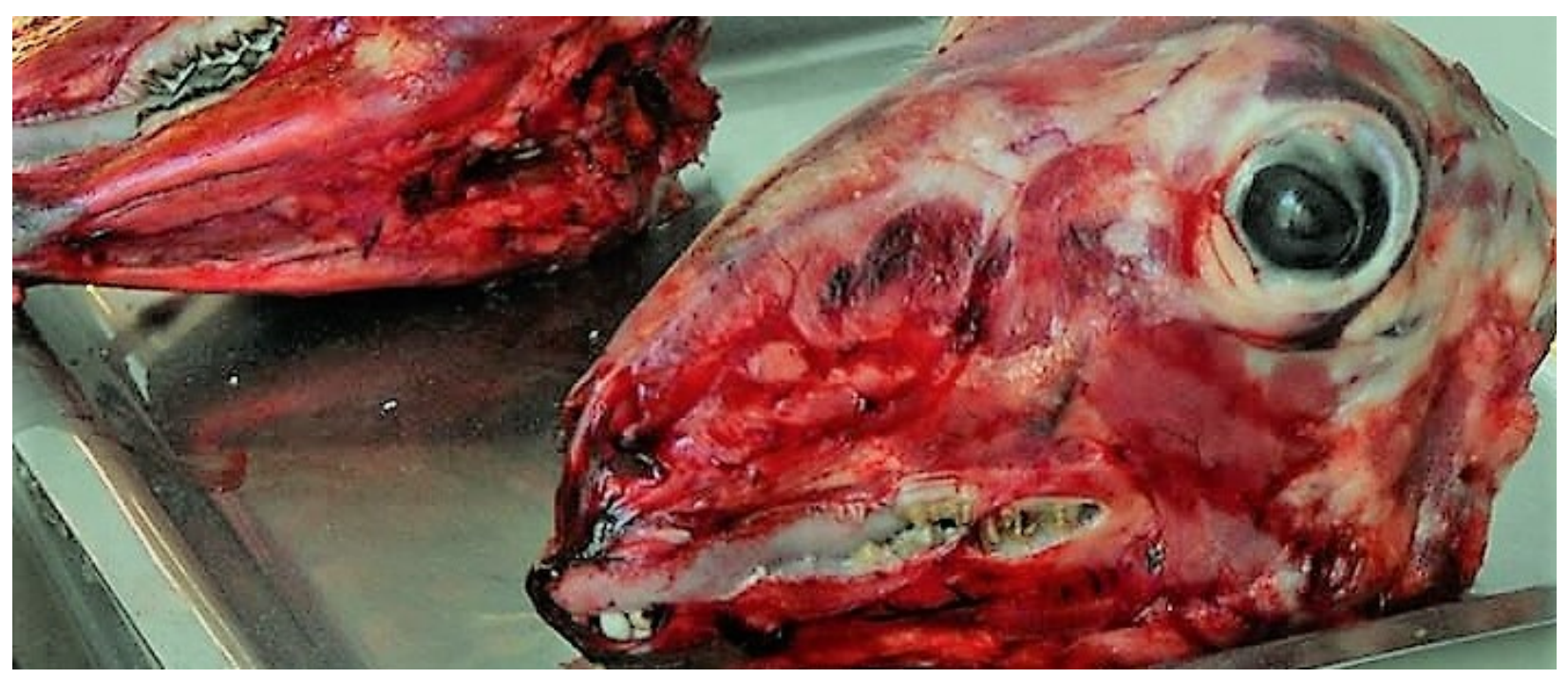

7. Ostriches Watching

Cultural and Pedagogical Inquiry, Fall 2017, 9(2), pp. 27-42

ISSN 1916-3460 C 2017 University of Alberta

http://ejournals.library.ualberta.ca/index.php/cpi/index 


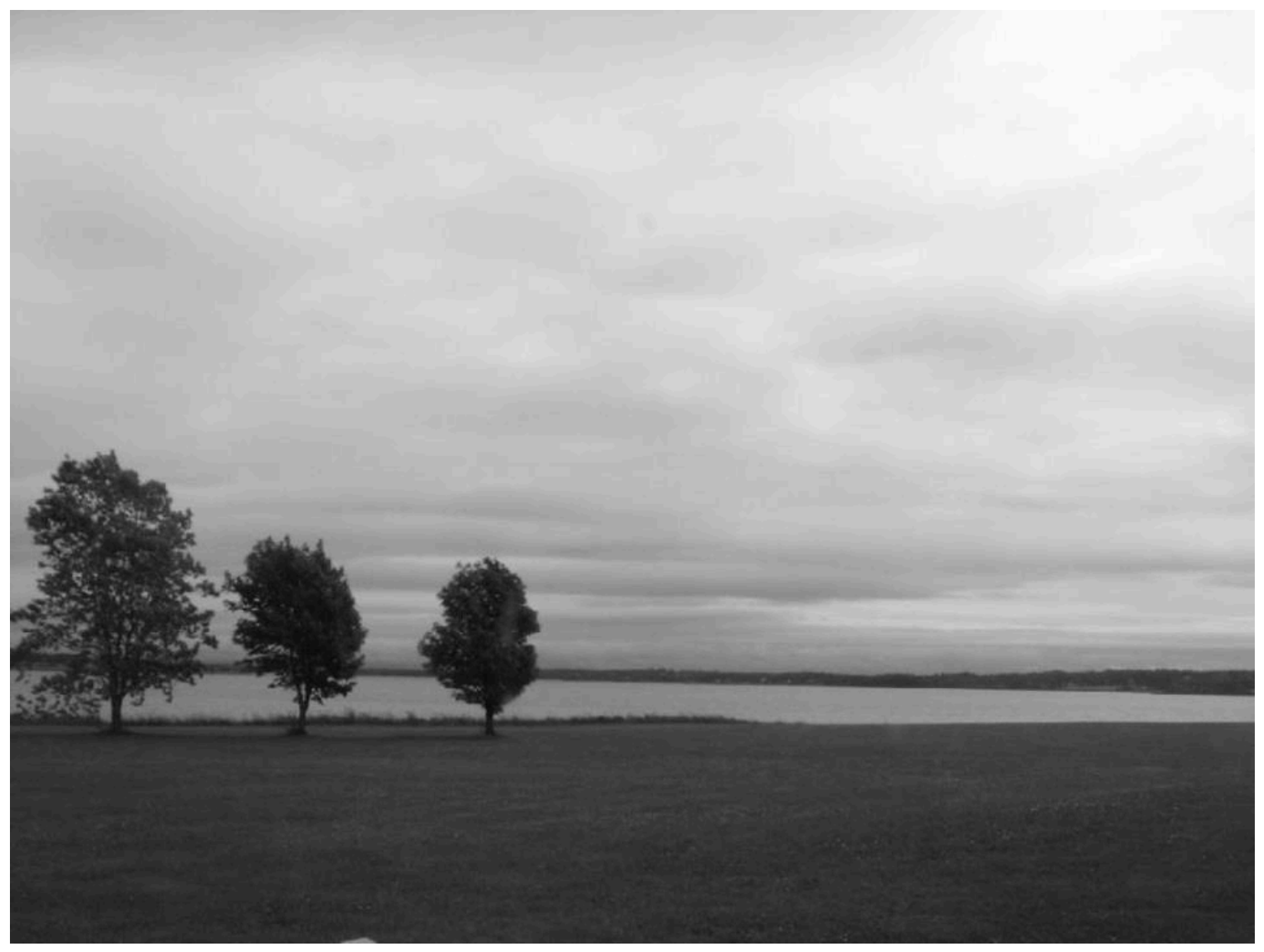

8. Three to the Left

Cultural and Pedagogical Inquiry, Fall 2017, 9(2), pp. 27-42

ISSN 1916-3460 (C) 2017 University of Alberta

http://ejournals.library.ualberta.ca/index.php/cpi/index 


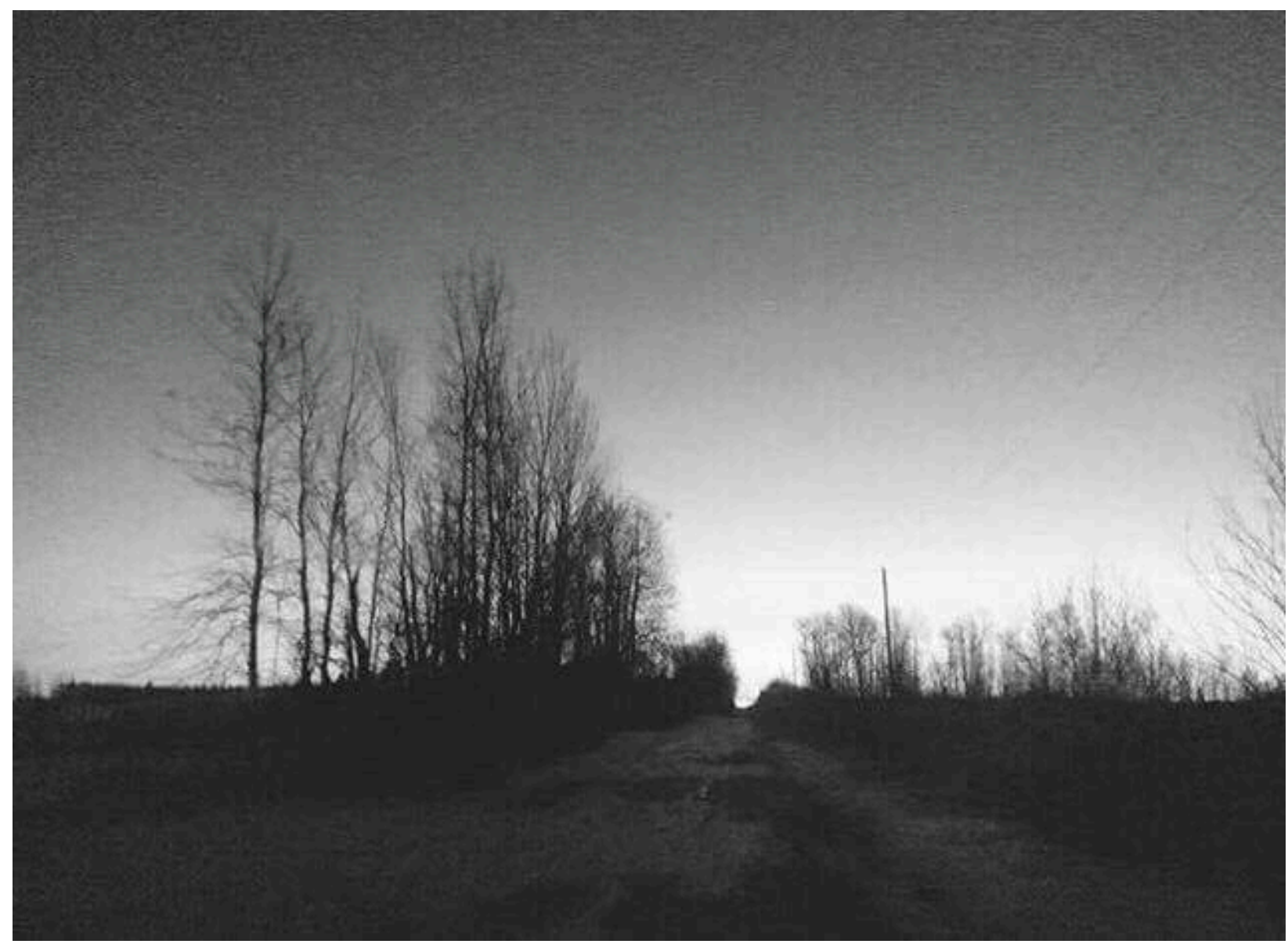

9. Deserted Road

Cultural and Pedagogical Inquiry, Fall 2017, 9(2), pp. 27-42

ISSN 1916-3460 C 2017 University of Alberta

http://ejournals.library.ualberta.ca/index.php/cpi/index 


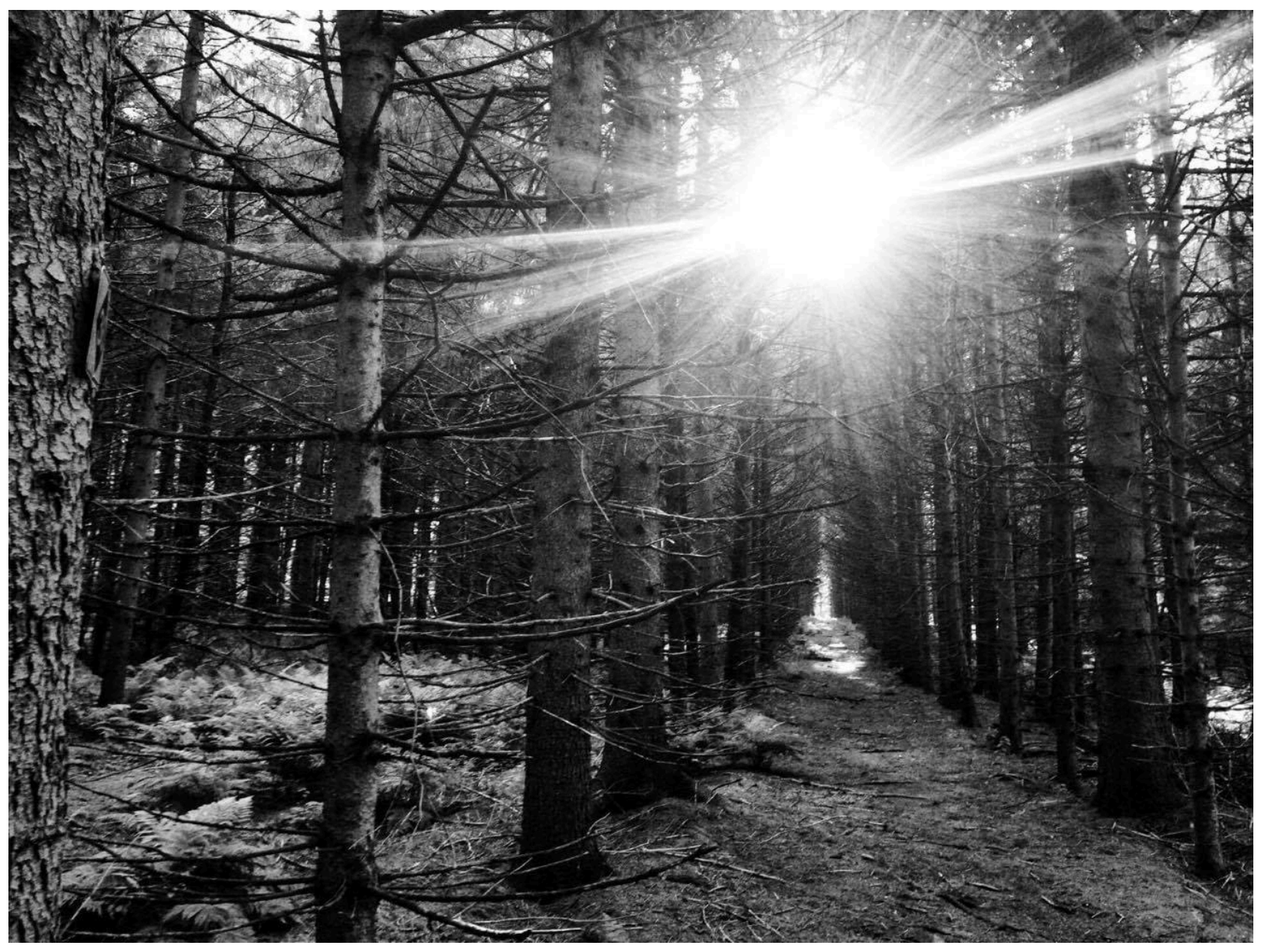

\section{Splinters}

Cultural and Pedagogical Inquiry, Fall 2017, 9(2), pp. 27-42

ISSN 1916-3460 C 2017 University of Alberta

http://ejournals.library.ualberta.ca/index.php/cpi/index 


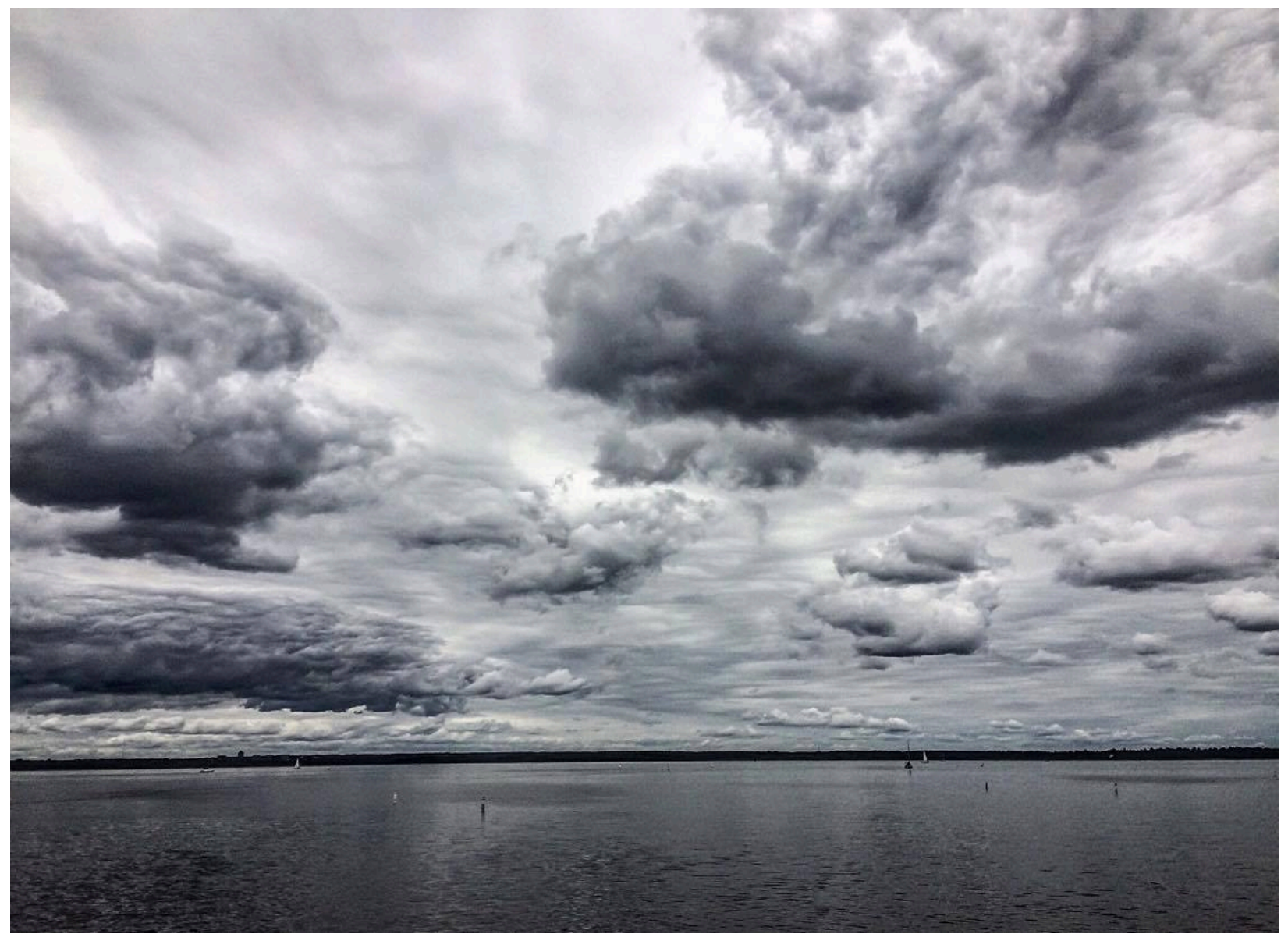

11. Into the Sea

Cultural and Pedagogical Inquiry, Fall 2017, 9(2), pp. 27-42

ISSN 1916-3460 C 2017 University of Alberta

http://ejournals.library.ualberta.ca/index.php/cpi/index 


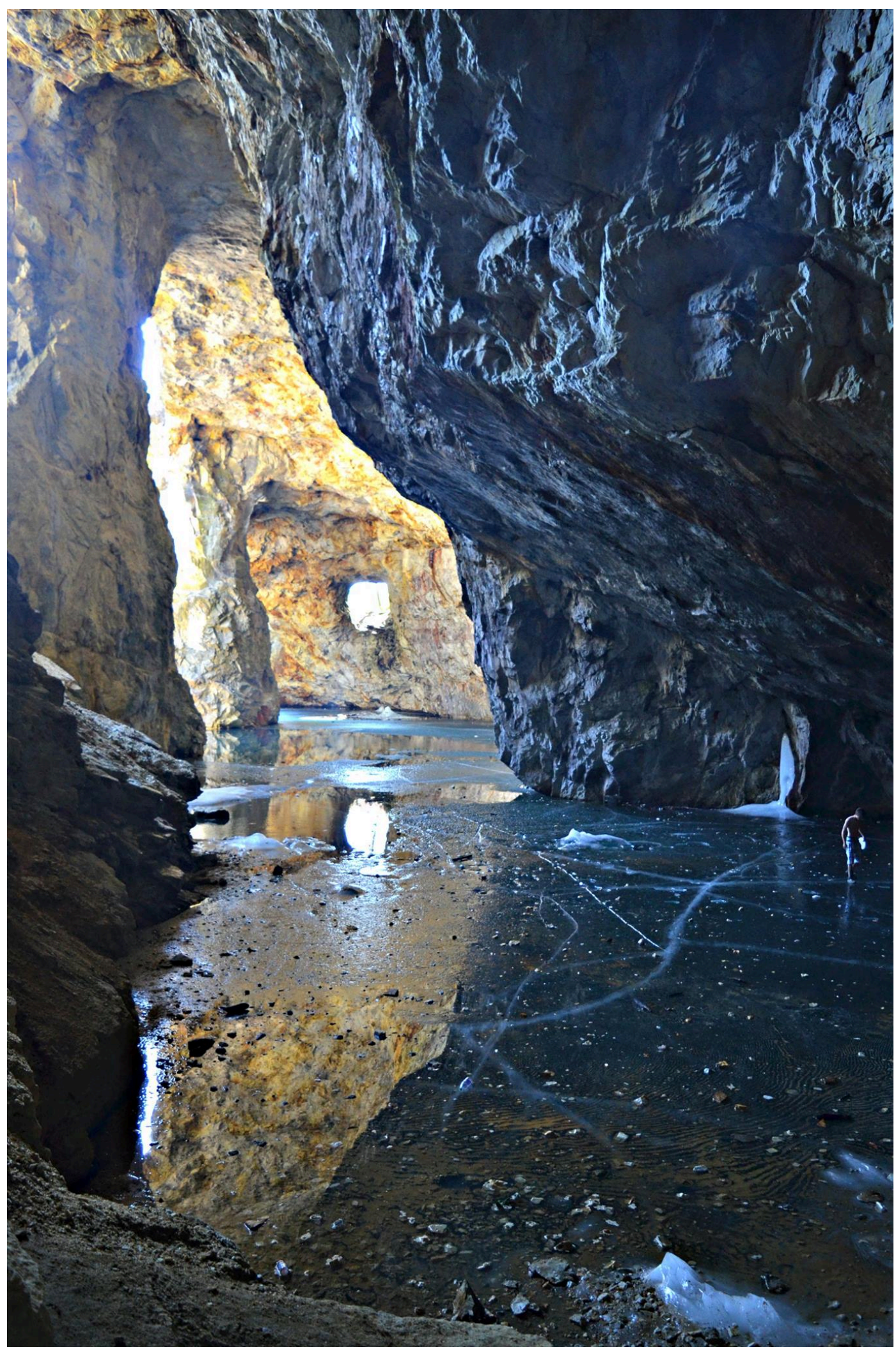

12. Navigating

Cultural and Pedagogical Inquiry, Fall 2017, 9(2), pp. 27-42

ISSN 1916-3460 (C) 2017 University of Alberta

http://ejournals.library.ualberta.ca/index.php/cpi/index 


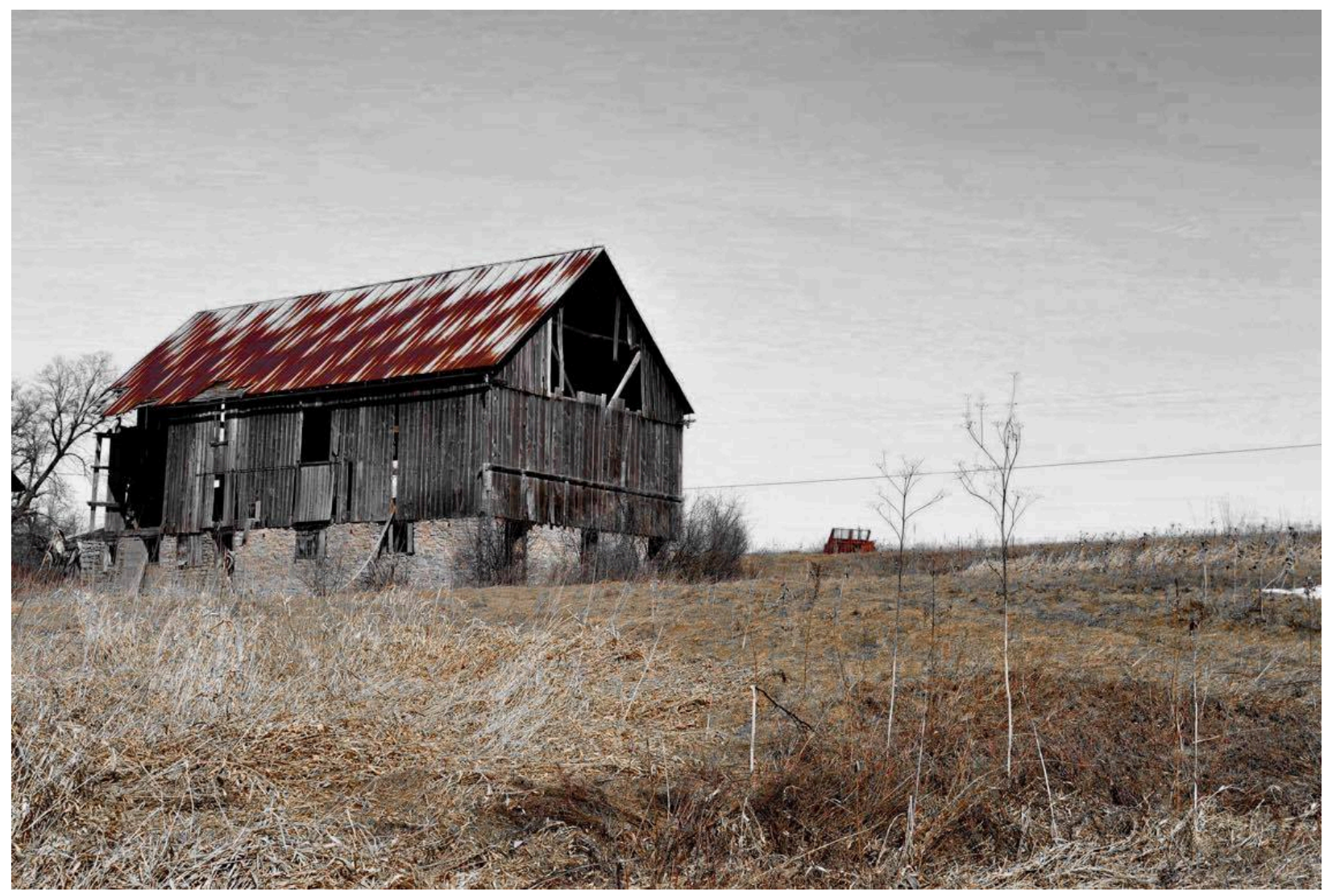

\section{Before}

Cultural and Pedagogical Inquiry, Fall 2017, 9(2), pp. 27-42

ISSN 1916-3460 (C) 2017 University of Alberta

http://ejournals.library.ualberta.ca/index.php/cpi/index 
14. Sunset

Cultural and Pedagogical Inquiry, Fall 2017, 9(2), pp. 27-42

ISSN 1916-3460 C 2017 University of Alberta

http://ejournals.library.ualberta.ca/index.php/cpi/index 


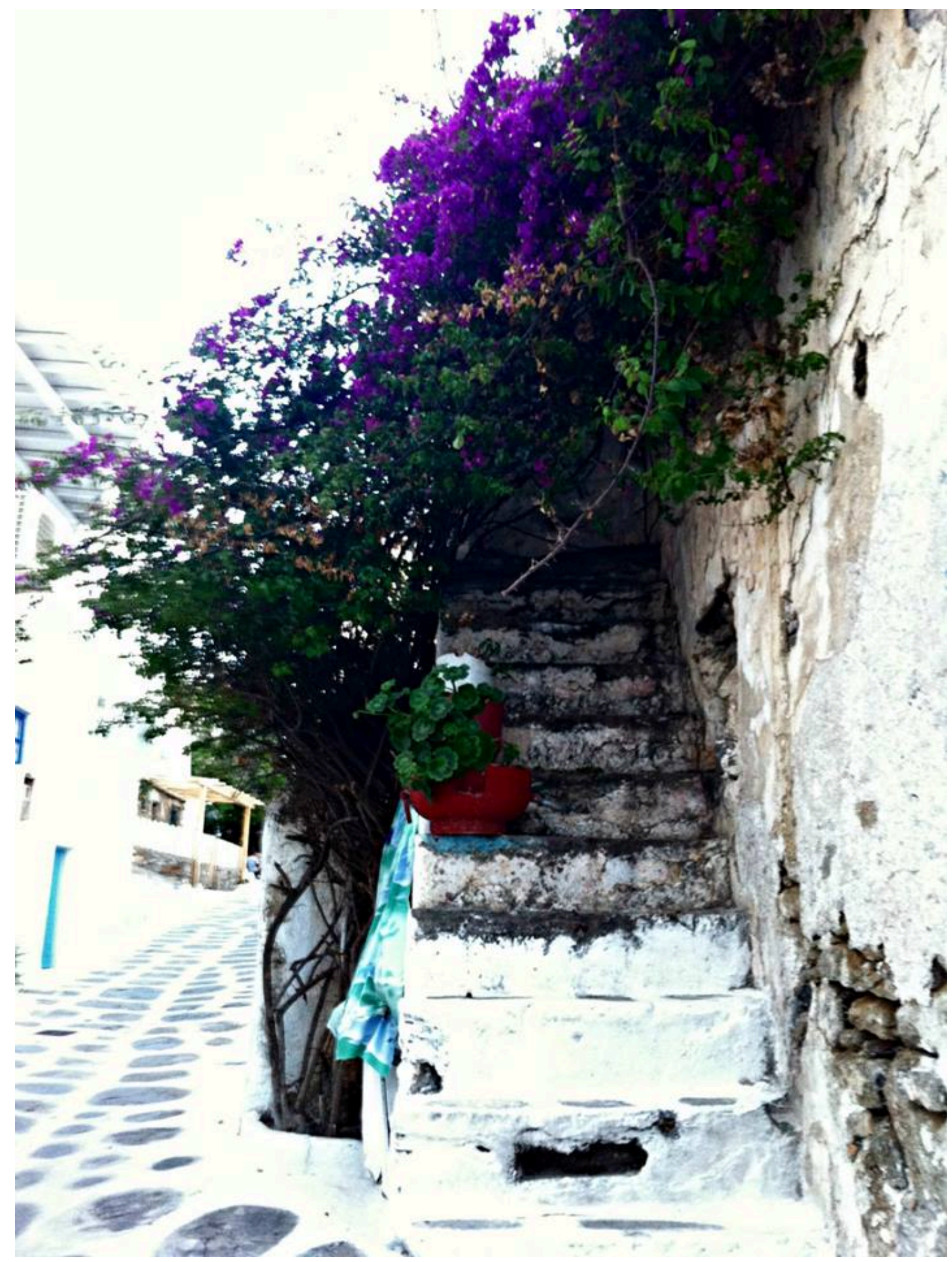

15. A Home of Broken Beauty

Cultural and Pedagogical Inquiry, Fall 2017, 9(2), pp. 27-42

ISSN 1916-3460 C 2017 University of Alberta

http://ejournals.library.ualberta.ca/index.php/cpi/index 